$12-1988$

\title{
Orthodoxy and revisionism in American demography
}

\author{
Dennis Hodgson \\ Fairfield University, hodgson@fairfield.edu
}

Follow this and additional works at: https://digitalcommons.fairfield.edu/sociologyandanthropologyfacultypubs

Archived with permission from the copyright holder.

Copyright 1988 Wiley and Population Council.

Link to the journal homepage: (http://wileyonlinelibrary.com/journal/padr)

\section{Peer Reviewed}

\section{Repository Citation}

Hodgson, Dennis, "Orthodoxy and revisionism in American demography" (1988). Sociology \&

Anthropology Faculty Publications. 31.

https://digitalcommons.fairfield.edu/sociologyandanthropology-facultypubs/31

\section{Published Citation}

Hodgson, Dennis. "Orthodoxy and revisionism in American demography." Population and Development Review 14, no. 4 (December 1988), pp. 541-569.

This item has been accepted for inclusion in DigitalCommons@Fairfield by an authorized administrator of DigitalCommons@Fairfield. It is brought to you by DigitalCommons@Fairfield with permission from the rightsholder(s) and is protected by copyright and/or related rights. You are free to use this item in any way that is permitted by the copyright and related rights legislation that applies to your use. For other uses, you need to obtain permission from the rights-holder(s) directly, unless additional rights are indicated by a Creative Commons license in the record and/or on the work itself. For more information, please contact digitalcommons@fairfield.edu. 


\title{
Orthodoxy and Revisionism in American Demography
}

\author{
DENNIS HODGSON
}

IN HIS 1986 PRESIDENTIAL ADDRESS TO THE Population Association of America, Paul Demeny (1986: 473) noted a "substantial shift" occurring among "knowledgeable observers" of the demographic scene: a move away from viewing high fertility and rapid population growth as problems. "Revisionists" are attacking "orthodoxy," some even proclaiming a "happy banishment of the population problem." Such a shift in perspective is reminiscent of the 1950s, when what Demeny labeled "orthodoxy" rose as a counterpoint to a demographic transition theory view of Third World population growth (Hodgson, 1983: 10-20). In the United States the development of demographic thought relating population growth and development evidently has not followed the scientific ideal of an early stage of incomplete knowledge being replaced by a later stage of more complete knowledge as theory is continually molded to better fit reality. Sharp breaks, not steady refinement, mark its path. Why?

There are those ("internalists") who see paradigmatic change within the social sciences as being basically independent of outside forces, and others ("externalists") who see social, economic, and political conditions as being the prime determinants of such change (Unseem, 1976: 147-148). An internalist analysis of American demographic thought on population and development would highlight the periodic inability of accepted theory to explain or predict a changing demographic reality. An externalist analysis would highlight how changing historical conditions periodically alter the agenda of those examining this relationship, inducing them to view it from a different angle. Each approach warrants examination. Both "internal" and "external" factors behind the rise of orthodoxy in the 1950s and revisionism today will be investigated. 


\section{The emergence of orthodoxy in}

\section{American demography: 1945-65}

From the vantage point of the late 1980s, what passes for orthodoxy in American demography is a perspective founded on two basic assumptions: rapid population growth in nonindustrial societies is a significant problem, and providing contraceptives to peasant couples can lower fertility prior to industrialization. Under orthodoxy, demographic trends are viewed as determinants of economic trends, rapid population growth as a cause of continued underdevelopment. Lowering fertility becomes a way of facilitating structural change.

Yet orthodoxy's novel assertion about the possibility of induced fertility decline in agrarian societies is nowhere to be found in 1945. The consensus of American demographers then was that demographic change occurs in response to structural change. With the formulation of transition theory in the mid-1940s (Kirk, 1944; Notestein, 1945; Davis, 1945; Thompson, 1946), American demographers had produced a unified theory apparently capable of explaining worldwide demographic trends. All demographic trends, especially fertility decline, were viewed as being responses to the variety of structural changes commonly subsumed under the rubric of "the modernization process." In a very real sense transition theory represented the culmination of 60 years of research on the socioeconomic determinants of Western fertility decline. Transition demographers felt comfortable arguing that the fertility level of any society could be understood by analyzing the components of its social system (Notestein, 1945: 39-40; Davis, 1948: 561562); it was "determined" by socioeconomic conditions.

Sixty years of demographic research implied that access to contraception played a minor role in "explaining" fertility decline. True, much of Western fertility decline was due to couples practicing birth control, but access to birth control had never been viewed as an independent variable affecting fertility (Notestein, 1945: 40). The timing and extent of Western fertility decline had not been related to advances in contraceptive technology. In most Western countries the spread of contraception took place in a hostile environment, with governments and religions expressing strong opposition. Long ago it had been concluded that fertility declined when the motivation to have children changed, not the ability to control fertility (Thompson, 1930: 115-116; Stix and Notestein, 1940: 150). Motivation changed in response to structural changes in the social system.

Inducing fertility decline by improving access to birth control had been viewed as dubious policy back in 1930 (Thompson: 331-332):

Great social changes do not take place by fiat. They must evolve slowly in response to changed conditions of life, as adjustments to an alteration in the status of individuals in the social and economic life of the community. An 
even more effective way to spread the practice of birth control than by mere propaganda is to aid those changes in social organization and individual status that will demand a new adaptation on the part of every person, an adaptation in which the advantages of smaller families will be obvious.

Regine Stix and Frank Notestein (1940: 153) spoke in similar terms: "The situation will not be altered by making modern contraception available to populations that have not utilized the folkway methods at their disposal." Gilbert Beebe (1942: 89) had explained why: "If the role of woman be that of wife and mother, with no vital functions taking her from home and family, and with important values realizable only in and through a large family, large families follow as a matter of course." According to transition analysis industrialization was a necessary prerequisite for fertility decline (Moore, 1945: 121): "Nor is any immediate solution for crowding on the land to be found in declining fertility. Falling birth rates may only be expected in an urban, industrial environment."

Yet by the mid-1950s a new view was being adopted by American demographers (Davis, 1954: 87-88): "India has a chance to be the first country to achieve a major revolution in human life-the planned diffusion of fertility control in a peasant population prior to, and for the benefit of, the urban-industrial transition." Philip Hauser (1958: 14-15) noted that "most students of population in Western countries" had adopted "a neoMalthusian position" that sees "reduced rates of population growth as essential aspects of long-run social and economic advances in the densely peopled agrarian societies of today's world."

Were there "internal" factors behind the rise of orthodoxy? Did the transition framework lose its ability to explain worldwide demographic trends? Did orthodoxy arise because it was better able to do so?

\section{Internal factors}

Demographic trends from 1945 to 1955 , both in industrial and nonindustrial societies, did raise questions about the adequacy of transition theory. Within some industrial societies transition theory lost its explanatory power when the long-term decline in fertility ended and a sharp upward movement began. American demographers had focused their attention upon the diffusion of conscious fertility control throughout the populations of industrializing and urbanizing societies. When this diffusion neared completion, Western fertility trends suddenly became unpredictable and "unexplainable" within the transition framework. Although demographers had considered "modernization" to be a process-a term that implied the existence of a beginning and end - they had not reflected upon what factors might become the prime determinants of fertility trends after the pattern of consciously controlled fertility had spread to a substantial majority of a population. They assumed 
that no significant fertility changes (at least no sharp upward movements) would occur after the birth rate reached low levels. This assumption proved wrong.

The loss of transition theory's explanatory power for fertility in industrial societies was mainly a theoretical problem for the discipline. The same sharp upward trend in fertility that belied the label given industrial societies by transition theorists-areas of "incipient decline"-also brought a resolution to the major perceived "population problem" of this group of societies: the prospect of depopulation. Few outside the field were traumatized by the baby boom. For those in the field, its appearance marked the end of an era. The agenda in place since the turn of the century, understanding the reasons behind Western fertility decline, dissolved as the boom erased fears of depopulation.

In the nonindustrial world an "unexpected" trend became evident to American demographers during the 1950s: rapid mortality decline that "did not depend on general economic development" (Davis, 1956a: 314, 1956c; Stolnitz, 1955, 1956a, 1956b). Transition theory had emphasized the role played by socioeconomic development in bringing about mortality decline (Taeuber, 1958: 257): "Economic advance and social change were necessary bases for improving health and declining mortality." Western mortality decline was thought to be primarily due to the improvements in diet and housing associated with rising levels of living. Mortality decline in colonies was primarily credited to mother countries implementing changes that increased the food supply and improved the transportation system. Even public health innovations and medical advances were thought to require the adoption of Western science, public education, and "other institutions of modern society" (Davis, 1948: 609). Mid-century mortality trends caused many to question the transition notion that mortality decline was basically a consequence of economic development.

George Stolnitz (1955: 53), for example, noted that the factors responsible for the dramatic downturn in the mortality of "the world's impoverished nations" were "all of recent origin" and not the same as those that had lowered Western mortality: "The primary role of international rather than national health agencies, the use of antibiotics, the development of cheap yet effective methods for combating malaria-each of these is very nearly a mid-century innovation." Kingsley Davis (1956a: 314) highlighted the fact that contemporary mortality decline was divorced from the process of economic development, caused by the "diffusion of death-control techniques which did not depend on the diffusion of other cultural elements or basic changes in the institutions and customs of the people affected." A "paradoxical" association of rapid population growth and continued widespread poverty arose, a "grotesque" example of "human self-frustration" (Davis, 1956c: 53). Davis argued (1956a: 318) that "economic development 
alone cannot be counted on to save a situation over which it has so little control and by which it is itself so greatly influenced."

Mortality decline accelerated population growth in an alarming manner. Earlier notions about what constituted a "high" rate of population growth had evolved from study of the Western experience. Rates of over 1.5 percent a year were commonly considered quite high. During the period from 1950 to 1954 Davis (1956c: 58) noted that Costa Rica averaged a 3.7 percent annual increase, Formosa a 3.5 percent increase, Malaya a 3.0 percent increase, Mexico a 2.9 percent increase, and the list went on. Although population/resource concerns made the immediate postwar population crisis an especially "Asiatic" one, early on (Vance, 1952) it was recognized that "simple and inexpensive" methods of death control threatened the modernization chances of all nonindustrialized societies. Rapid population growth that was not a consequence of economic development might very well prove its nemesis.

American economists during the 1950s emphasized the role played by capital accumulation in the development process. Underdevelopment represented a workforce with little capital stock, and development was a process of adding to that stock. Rapid population growth produced high dependency ratios that increased the need for "demographic investments" and thereby limited the capital available for more directly productive investments. Some theorists (Leibenstein, 1954; Nelson, 1956) developed models describing a "low-level equilibrium trap" in which population growth stymied growth of per capita income. The specter of growing numbers living at subsistence levels, making economic development increasingly improbable, was presented as a real possibility (Leibenstein, 1954: 70, 194). Others (Coale and Hoover, 1958; Enke, 1963) quantified the economic cost of continued high fertility and found it substantial. Demographic trends affected both economists and demographers, and the fears of each heightened those of the other (Taeuber, 1958: 251-252): “The present world-wide controversy on feasible rates of economic development and probable rates of population increase is a product of this new situation in which the reduction of mortality is freed temporarily from necessary relations with economic developments." If rapid population growth were forestalling the economic transformation that could bring about fertility decline, transition theorists had a crisis and no humane solution.

Detailed demographic studies of rapid mortality decline reinforced these fears. Countries with high fertility traditionally have a high proportion of their population in the younger ages. It was found (Lorimer, 1951; Coale, 1956; Stolnitz, 1958) that the postwar mortality decline, because it occurred most sharply in the younger age groups, was actually further increasing the proportion of the young. By the end of the 1950 s it was not uncommon for a Third World country to have nearly half its population under the age of 
15. A situation in which there was one person in the nonproductive ages for every individual in the economically active years seemed to document a "demographic stumbling block" to economic development efforts. Any country doubling its population every 25 years, irrespective of its current size and density, would have difficulty industrializing. By the late 1950s all rapidly growing Third World populations, Latin American and African as well as Asian, were assumed to be demographically handicapped in their struggle to industrialize.

So there is in fact a plausible "internalist" explanation for why the transition framework was questioned during the 1950s. Mortality decline caused by "extraeconomic factors" (Davis, 1958a: 9) resulted in unprecedented rates of population growth that made it no longer so easy to view "population trends as a function of 'progress" " (Kirk, 1944: 28). Yet what of orthodoxy's novel assertion that fertility in agrarian societies could be lowered directly? Again, it ran counter to 60 years of research on the determinants of fertility trends. Did it rest on new demographic evidence of access to contraception inducing fertility decline among peasant populations? No. The absence of such evidence, more than its presence, was responsible for the rise of this view. Empirical support for this novel assertion was slight. Davis (1950: 17) could point to women in "a rural section of India" responding to a question- "How many living children should a woman have when she is 40 ?"-with a "modal preference for two or three children" as evidence of an "incipient" fertility decline that might be activated with an "all-out governmental campaign to diffuse contraception." Notestein (1953) could write that Bulgarian fertility had recently declined while that society was still predominately agrarian. Such internalist explanations for the rise of orthodoxy's novel assertion seem strained.

\section{External factors}

It was nondemographic factors present at mid-century, factors that made it difficult to view fertility with a disinterested eye, that made American demographers advocate providing peasants with contraceptives to lower fertility. The unbalanced vital rates of the nonindustrial world were thought to be an inherently unstable and hence transitory phenomenon whose dénouement would be either a return of high mortality or fertility decline. Given the paucity of urban-industrial development, transition analyses generated predictions of mortality increase, but now these predictions were used as a foil to convince skeptics of the necessity of bringing contraception to peasants (Davis, 1951: 230-231; 1953: 17; Notestein, 1950: 343-344; Vance, 1952). Orthodoxy was as much a development strategy as a demographic perspective: induced fertility decline could forestall famine, economic catastrophe, and political turmoil in the nonindustrial world, while 
permitting gradual structural change and steady economic growth. This was a very desirable scenario, and not just for demographic reasons.

Back in 1946 the unbalanced vital rates resulting from colonial domination had been labeled "the Malthusian dilemma of all colonialism" (Thompson: 313), and the demise of the colonial system was predicted. That came to pass. The collapse of the colonial system coincided with the arrival of the Cold War. The sharp postwar drop in mortality took on new political implications. The ensuing rapid population growth threatened to thwart the industrialization plans of Third World nations, many of them newly independent. Retrograde or stagnant economic conditions were thought to be a breeding ground for communism. This coalescing of historical conditions gave added urgency to curtailing rapid population growth, especially in Asia (Taeuber, 1965: 79): "Given the delayed modernization, the synchronization of nationalist awakening and communist political advance, and the coincidence of both these with the scientific and technological advances in mortality control, Asia's problems of population, development, and war become hazards not alone to Asia but to the whole world." First foundations and later governments were willing to infuse millions of dollars in what was then a quite small discipline for research that might aid in controlling fertility. The Cold War, the end of colonialism, and the availability of funds for population control were "external" factors that assured orthodoxy's rise and helped mold its contours. They warrant a detailed examination.

The Cold War The polarization of the world into "free" and "communist bloc" during the 1950s was a change affecting everyone's vision. Other changes were examined to detect how they might influence this overarching competition. "The bi-polar contest overshadows all other aspects of contemporary world politics. Almost all specific issues, from population problems to uses of nuclear energy must be considered in its context" (Hauser, 1958: 15). The "uncommitted" third of the world was a "prize" to be won in a struggle between "the Communist and the free worlds" (Davis, 1956b: 354; Hauser, 1958: 14). Which model of development, Soviet or capitalist, would these nations adopt? "If the underdeveloped Communist nations demonstrate that they can achieve more rapid economic progress than the underdeveloped Western nations, the free way of life may well be doomed" (Hauser, 1964: 119). Which side would benefit from continued rapid population growth? "Success or failure in this fateful contest may well hinge on the ability of the nations involved to decrease their rates of population growth" (ibid). The Cold War forced policymakers and academics to face such questions; it helped mold a new agenda for demography.

If demographers had used transition analysis to answer these questions, a politically awkward situation would have arisen. The transition framework considered fertility decline to be largely the consequence of industrialization. 
The only solution to the problem of rapid population growth that directly flowed from this framework was stimulating rapid and extensive industrialization. The more rapid the population growth, the more rapid the industrialization had to be.

The Soviet Union was then the prime twentieth century example of planned and very rapid industrialization. In fact, during the early 1940s the Soviet case had even been used as an exemplar of how to deal with the "population problem." Notestein (1943: 173) had observed that "during the past twelve years she [the Soviet Union] has made the most rapid progress in industrialization that the world has ever seen." Furthermore he had argued that, with the Soviet Union's "enviable record in dealing with ethnic heterogeneity" and future potential for development, a solution to Eastern Europe's "demographic problems may be rapid" if this area were "absorbed" by the Soviet Union. He had even concluded his analysis (1943: 174) by observing that "the Soviet Union, given a little political luck, will be the strongest single power in the world, and will occupy a dominant position on the Eurasian Continent."

In the early 1940s such statements might be understandable. The example of a nation with a planned and very rapid industrialization experience was heartening for observers who then believed that industrialization necessarily preceded fertility decline and who looked for a solution to the problems posed by population growth. But when America's former ally became its most feared competitor, when the Third World became an arena in which the competition was fought, and when rapid population growth appeared to foreclose the possibility of repeating the Western industrialization sequence, such thinking might no longer appear either understandable or defensible. The 1950s was such a time.

Mid-century social, political, economic, and demographic conditions were judged propitious for the spread of communism (Taeuber, 1958: 243): "The very factors of poverty, ill health, and ignorance that make the creation of responsible democratic governments so difficult render people susceptible to the Communist appeal. And the present interrelations of poverty and population density in the agrarian societies reserve the high fertility that sends populations upward while slowing the possible developments that might lead to reduced fertility and lessened growth." Analysis of regional economic trends (Kuznets, 1958) indicated that over the first half of this century the income gap between the less and more developed regions had increased and that while income inequality had lessened within developed regions it had increased within less developed regions. Simon Kuznets was led to conclude (1958: 116):

The political misery of the poor, the tension created by the observation of the much greater growth of other communities, the failure to utilize the patently 
increasing potential of economic production and welfare, may only have increased. . . . There is a clear probability of internal tensions that provide drives directed simultaneously at some higher level of over-all economic performance and, perhaps contradictory, at a rapid equalization of income and opportunities. It takes little imagination to spell out the consequences of such a situation. (emphasis in original)

The consequence most clear to American demographers was the need to solve the population problem. With the United States having yet to include a birth control component in its foreign aid programs, demographers found themselves employing Cold War arguments in an attempt to influence US policymakers:

The weapon the free world is mainly dependent upon to assure that the uncommitted part of the world will at least be neutral, if not pro-free world, is that of providing technical assistance designed to raise levels of living. The success of the free world's technical assistance programs may well depend on the satisfactory solution of the population problem. (Hauser, 1954: 187-188)

What the United States would like to see them [leaders of underdeveloped countries] do is to foster peaceful and democratic industrialization, a rising level of living, and, in general, adherence to our side. To this end we have given or lent money for agriculture, industry, transportation, public health and arms. We have maintained that this is an effective way to head off Communism because, as we say, chronic poverty breeds Communism. This reasoning has much to commend it, but it ignores population trends and thus runs the danger of underestimating or misinterpreting the requirements for economic development. (Davis, 1958b: 296)

Interestingly, when President Lyndon Johnson (1966: 321) first asked Congress for fertility control funds, he did so on the basis that high population growth rates "challenge our own security." In the Cold War years of the 1950s American demographers adopting the orthodox view were gaining a solution to both a population and a political crisis, while simultaneously losing an association with a perspective that considered the Third World's population and economic problems a legacy of Western colonialism.

Cold War concerns might also be responsible for orthodoxy's emphasis on a family planning approach to population control. Attention at midcentury was focused on "the race between India and Communist China," between "the Communist approach" and "democratic methods" (Hauser, 1964: 119). With this contest being "watched with intense interest by the peoples of underdeveloped areas throughout the world" (Hagen, 1958: 127), its outcome was thought to be of great importance to the "Western bloc." In the Indian government the United States had an ally who accepted "the fact that both economic advance and the slowing of population growth can be achieved through democratic processes" (Taeuber, 1958: 252). Voluntary 
family planning was an attempt at population control that, although problematic from a demographic point of view (assuming, as it did, that peasants would simply avail themselves of the services offered), was "democratic." It was quite compatible with the free world's overall development strategy for the uncommitted world. Any contention that coercive birth control might be needed to control the population of India and so save it from the evils of totalitarian communism, although corresponding more closely with past demographic research, would hardly have been so compatible.

Decolonization Nationalist sentiment mobilized the masses, and colonial empires crumbled during the postwar era. The decolonization of the world was a change of immense significance. With political independence came a rise in expectations and the universal quest for industrialization. With the allegiance of newly independent nations being sought in a "bi-polar world," their hopes and problems became a matter of concern to policymakers and academics in the United States.

The original formulators of transition theory in the United States expanded its explanatory power beyond the industrialized world by including a "colonial explanation" of the nonindustrial world's demographic trends (Kirk, 1944: 28-35; Notestein, 1945: 50-57; Davis, 1945: 5-11; Thompson, 1946: 251-318). Colonies had an attenuated modernization experience that caused mortality to fall but not fertility. Colonial powers, seeking an assured source of raw materials and a productive labor force, consistently introduced certain changes in their colonies: the rationalization and commercialization of agriculture, the maintenance of internal order, improvements in transportation and communication, and the control of disease. Famines and epidemics declined. But colonial powers, desiring markets for their own manufactured goods, prevented or failed to foster industrialization in their colonies. The changes that led to lower fertility in the West did not occur, fertility remained high, and populations grew. This explanation placed the "blame" for unbalanced vital rates on the unwillingness of colonial powers to foster industrialization in their colonies.

Decolonization vitiated transition theory's colonial explanation. With political independence came the universal desire to implement programs of rapid industrialization; no longer could unbalanced vital rates be explained by any lack of such desire. With Third World governments, not colonial powers, setting policy, the way unbalanced vital rates returned to equilibrium would be influenced by their action or inaction. Ideologically this meant that responsibility for continued population problems could be passed from the First World to the Third World (Taeuber, 1958: 259): "Since the responsibilities of leadership now inhere in the peoples themselves, evasion of a population aspect to economic difficulties and political instabilities can no longer proceed through condemnations of colonial systems." Practically this 
meant that American demographers concerned with the nonindustrial world's demographic trends had a new audience to address: Third World leaders. This change in audience was to have a profound impact on demography in the United States.

What message did American demographers have for these leaders? Nearly all (Vance, 1952; Taeuber, 1952: 37; Notestein, 1953: 25; Davis, 1953: 17) had concluded that current high levels of population growth made impossible a repetition of the Western sequence of economic and demographic change. Matters were more serious: a real population crisis existed. With "the high rate of capital formation which Communist countries can maintain through totalitarian methods" (Hagen, 1958: 122) thought to give an edge to the Soviet model of rapid industrialization, recommending any developmentalist solution to this crisis was problematic. With the special ideological attractiveness of the communist development strategy to newly independent peoples having been recognized (Watnick, 1952), a central task for American demographers became convincing Third World leaders that population control was both needed and possible.

Simulation studies, such as that of Ansley Coale and Edgar Hoover (1958), were begun "to let us study what the economic consequences of alternative courses of events would be" (Notestein, 1954: 168). Calculating the costs of continued high fertility and the benefits of lower fertility played to the development hopes and fears of Third World leaders and helped convince them of the need for fertility control. Knowledge, attitude, and practice (KAP) surveys were undertaken throughout the Third World. Their findings, which seemed to show most respondents desirous of controlling their fertility, were used to convince often-skeptical leaders that effective family planning programs were possible (Berelson, 1964: 11). Foundations funded the establishment of graduate-level population programs at American universities focusing on Third World problems and of fellowship programs that brought many Third World students to them. Here they learned to view fertility in an orthodox fashion, as a malleable variable capable of being shaped to meet the development needs of their societies.

The decolonization of the nonindustrial world affected American demography by changing its audience, influencing its choice of topics, and attracting to it new levels of funding that dramatically affected its size and shape.

Funds for fertility control Funds for fertility control began flowing in 1952. John D. Rockefeller 3rd, concerned with the growing imbalance in Asiatic vital rates, called a conference at Williamsburg, Virginia, under the auspices of the US National Academy of Sciences to examine the effects of population growth (Notestein, 1982: 676-677; Bachrach and Bergman, 1973: 44-46; Population Council, 1977). Five months later the Population 
Council was founded with Rockefeller as its president. During that same year the Ford Foundation began funding population activities (Caldwell and Caldwell, 1986: 32). Until the mid-1960s, when the US government began expending large sums, the majority of funds supporting global fertility control came from the Ford Foundation and various Rockefeller sources, much of it funneled through the Population Council.

The concerns that led to this funding were, in many ways, similar to those influencing demographers. Rockefeller (1974: 2-3), reminiscing about the early years of his involvement with the Council, reflected on his motivations: "For many years a sense of urgency caused me to concentrate on the family planning approach. It was generally recognized in those days that industrialization led to low birth rates, but there were few countries that had the capital and the resources to industrialize." Notestein (1968: 553), in relating the original mandate given the staff by the trustees of the Council, revealed their concerns: "Believing as they did that the mounting tempo of growth among the world's poorest people represented a major threat to socialeconomic development, to political stability, and indeed to human freedom, they were concerned with the problems of population growth."

During the 1950s both the Ford Foundation and the Population Council emphasized research over action (Piotrow, 1973: 14-15). Reproductive physiology and demographic research were the two areas highlighted. Research on oral contraceptives and intrauterine devices produced great optimism about improvements in contraceptive technology. The public, already feeling the first stirrings of the sexual revolution, became more accepting of the open discussion of sexual topics. The foundations' inhibitions about supporting "action" programs to control fertility lessened and by the early 1960s substantial funds for direct technical assistance began flowing.

The expenditures on demography had a profound impact. In 1950 it was taught at the graduate level in only three places. Seven additional programs were added between 1951 and 1961, nine more between 1961 and 1967 (Stycos, 1967). From 1952 to 1968 a dozen population centers in the United States were the recipients of major Ford Foundation funding (Caldwell and Caldwell, 1986). The Population Council aided demography's rapid growth with its fellowship program and institutional grants. These funds changed a small group of scholars sharing an interest in a subject matter into a substantial group of researchers attempting to resolve a crisis.

The growth of demography was not limited to training centers. Beginning in the 1960s numerous journals were launched in a field that formerly had only a bibliographic index as a national journal. Two of these were directly published by the Population Council (Studies in Family Planning and Population and Development Review), another was started with seed money from the Ford Foundation (Demography), and still another relied for funds on the US Agency for International Development (International Family Plan. 
ning Perspectives). Funds for fertility control both expanded and shaped American demographic literature.

In the mid-1960s the US government began to expend significant funds on fertility control. Department of Health, Education, and Welfare expenditures increased from $\$ 4.6$ million in 1965 to $\$ 14.7$ million in 1969; USAID funding increased from $\$ 10.5$ million in 1965 to $\$ 45.4$ million in 1969 and to $\$ 123$ million by 1972 (Caldwell and Caldwell, 1986: 102-104). Most of the funds came to flow through the Office of Population at USAID, which did not follow the same strategy as had the foundations. For a variety of reasons-some personal, relating to the convictions of its director of population activities; and some institutional, relating to a different specification of its mission-USAID resolved to expend funds so as to maximize their immediate impact on fertility (Warwick, 1982: 45-51). Most of its money was spent to support family planning programs, with only a small portion going to research or institutional support.

\title{
Institutionalizing orthodoxy
}

Funding for fertility control had its biggest impact on American demography by institutionalizing an orthodox agenda. Edward Shils (1970: 763) has aptly defined the process:

\begin{abstract}
By institutionalization of an intellectual activity I mean the relatively dense interaction of persons who perform that activity. The high degree of institutionalization of an intellectual activity entails its teaching and investigation within a regulated, scheduled, and systematically administered organization. It also entails the organized support of the activity from outside the particular institution and the reception or use of the results of the activity beyond the boundaries of the institution.
\end{abstract}

Institutionalization was the initial goal of those funding fertility control research. The organizations they established, such as the Population Council and the university-based population centers, provided the "relatively dense interaction" of persons engaged in the effort. Funding decisions directed academic attention to global population issues and produced individuals trained in a variety of academic specialties who had an interest in such issues. Contracts for fertility control research produced findings that could be put to use by governments and private organizations in developing their family planning programs. By the late 1960s this research had acquired all the characteristics of a well-institutionalized intellectual activity.

This institutionalization affected demography in two major ways. First, during decades when compelling evidence was lacking that family planning programs could lower fertility in agrarian societies, earmarking the majority 
of population research and training funds explicitly for family planning work (Bachrach and Bergman, 1973: 58-60) kept orthodoxy firmly entrenched within the discipline. Training centers were established that had an "international" orientation, with a curriculum focused on Third World population problems. Population centers accepting Ford Foundation funds were asked to make a "commitment" that "much of the money would be spent on Third World students and a considerable part of the balance on US students with Third World interests" (Caldwell and Caldwell, 1986: 61). A significant component of the funding of most population centers was "soft" contracts for family planning program development and evaluation research. This institutional environment did not foster much questioning of orthodox assumptions (Demerath, 1976: 54).

Second, the institutionalization of fertility control research gave it a life of its own, independent of demography. Other professionals, not concerned with disciplinary questions, were engaged in bringing about global fertility control. Medical and biological scientists were employed to develop new contraceptives, public health specialists to integrate the provision of birth control services into health care delivery systems, communications specialists to develop information campaigns. They did not have as their goal the furthering of demographic knowledge. Their goal was to develop ways of lowering fertility. Bernard Berelson described the situation in 1971 (p. 182):

A decade or more ago, when population was a relatively disregarded and financially poor field, it "belonged" to the professional demographer, university-based. To-day, when it is both popular and rich, it "belongs" to others as well-to non-demographic newcomers from the behavioral sciences, to "family planners" from the public health and medical fields, to bio-ecologists suddenly expressing grand rights of eminent domain, to lawyers or social workers or geographers or educators or political scientists attracted by the problem and/ or the prospects. The broad field of demography, or even of population studies, has recently been "contaminated" by alien (wrong?) notions, by different (lower?) standards, by demographic illiteracy, by "action."

Much of American demography became a subsidiary of a larger enterprise that "sought to assign to social science research on population issues the role of handmaiden in family planning programs" (Demeny, 1988: 466). The multidisciplinary fertility control effort was committed to a goal, not to a discipline or a method for approaching truth. Demography did not direct this effort, but only provided it with certain specialized services. The very "creation of university population programs was only an intermediate objective in the [Ford] Foundation's objectives" (Caldwell and Caldwell, 1986: 143); the ultimate objective was limiting population growth. To some extent, demography, with its theoretical baggage of transition theory, had to be supplemented (Bogue, 1965: 724): "The raison d'être for family planning 
research is the recognition that none of the theories or hypotheses being explored by traditional demography can provide the basis for a stepped-up 'crash' program for fertility reduction."

\section{Politicizing demography}

Funds for fertility control eventually worked to politicize American demography. Advocacy of global fertility control came to be identified, with some justification, as a policy position of the First World. Like "the links of a food chain" (Notestein, 1971: 82), the actions of a few concerned and influential individuals in the United States led to the involvement of foundations, universities, governments, and finally international organizations in this effort. By the end of the 1960s quite a number of voices were carrying the message: the World Bank, USAID, a number of Western governments, a variety of United Nations agencies, economists and demographers trained in Western universities, to name a few. Fertility control was one activity for which a Third World government could easily find First World monetary support (Piotrow, 1973: 145-158). This advocacy of Third World fertility control by First World institutions raised questions about motives. Controversy came to surround the issue, as evidenced at the World Population Conference at Bucharest in 1974.

Those initiating the conference, principally the United States, planned it to be a staging ground for a united worldwide effort to lower fertility (Finkle and Crane, 1975: 87). Yet the "world" divided. The head of the Indian delegation asserted "development is the best contraceptive" and was greeted with "the acclaim of most Third World participants" (Ford Foundation, 1985: 18). This slogan was not a call for dismantling family planning programs, and there was no such dismantling after the conference. It was a slogan that questioned motives and made a statement about priorities.

Discussion of the true nature or real extent of Third World "population" problems became the context for a global political debate (Finkle and Crane, 1975: 89; Mauldin et al., 1974: 377; Carder, 1974). The problems focused on were real ones: food shortages, underdevelopment, unemployment. But when assessing who or what was responsible for them, each side tended to adopt an interpretation that minimized its responsibility. The view that continued underdevelopment, unemployment, and malnutrition were fundamentally "population problems" had great attraction to policymakers in the First World. The cause of and the solution to problems could then be found in the Third World itself: rapid population growth was the cause and fertility control was the solution. What was needed from the First World was only the modest amounts of money and technical advice that were necessary to establish a fertility control program. President Johnson, perhaps too bluntly, had stated the case in 1965 (Piotrow, 1973: 90): "Let us act on the fact that 
less than five dollars invested in population control is worth a hundred dollars invested in economic growth."

The view that underdevelopment, unemployment, malnutrition, and rapid population growth were fundamentally caused by the ties of dependency that had bound and still bind the Third World to the developed world had great attraction to Third World policymakers. A solution to these problems, then, required a global redistribution of wealth and power: a new international economic order. Without it, global chaos, only one element of which was an "overpopulated" world, was likely to result. This solution required much from the First World. With the United States already having objected to a new international economic order, few Third World leaders at Bucharest, even those with active family planning programs at home, could resist making a point about the misplaced priorities of the United States (Finkle and Crane, 1975: 109).

In the context of this political debate, orthodoxy took on a decided political coloration. Since the late 1940s orthodox demographers had been identifying rapid population growth as a basic cause of Third World problems. During the 1950s they worked diligently to convince First and Third World policymakers of the need for fertility control and to document its feasibility. When motives were questioned in the late 1960s, they found themselves deeply committed, by past research and often by current employment, to a demographic etiology of Third World problems. At Bucharest they found themselves in the center of a highly charged political arena.

Ever since the first UN-sponsored population conference in 1954, orthodox demographers had faced the standard Marxist critique of neo-Malthusianism: a shroud used to mask imperialism and colonialism (Ryabushkin, 1954). With the deepening US involvement in Vietnam during the 1960s, this critique found growing receptivity even at home (Barclay, Enright, and Reynolds, 1970; Pradervand, 1970). The early and continuing interest of rich industrialists in population control was used to document its capitalist nature. Feminists (Mass, 1972, 1974; Gordon, 1974, 1976) highlighted links to the older eugenics movement, labeling Davis, Clyde Kiser, Notestein, Dudley Kirk, and Frank Lorimer "eugenist demographers" (Gordon, 1976: 396). Such questioning of scientific legitimacy by "unmasking" ideological roots was usually ignored by orthodox demographers, although occasionally countered in kind (Stycos, 1974). At Bucharest, though, an opponent of orthodoxy more insidious than Marxism emerged: a liberal version of developmentalism.

The argument that development will motivate couples to have small families sprang more from analysis of the Western experience than from Marxist theory. The failure of over a decade of family planning to substantially lower fertility in a number of societies had already led some to question it as a method of population control (Davis, 1967; Mamdani, 1972); giving 
contraceptives to peasant couples not desirous of small families would not lower fertility. Still considering rapid population growth a serious problem, some of the disenchanted argued for more coercive forms of population control (Davis, 1967: 738), while others called for redirecting development benefits to the impoverished to hasten their adoption of small-family ideals (Rich, 1973; Kocher, 1973). The political, economic, social, and ethical feasibility of coercive measures could be questioned by the orthodox (Berelson, 1969), but the "developmentalist" position proved more difficult to counter. The World Bank under Robert McNamara moved in a developmentalist direction (World Bank, 1974) and John D. Rockefeller 3rd (1974: 4) announced his conversion at Bucharest: "I now strongly believe that the only viable course is to place population policy solidly within the context of general economic and social development."

The adoption of a developmentalist World Population Plan of Action at Bucharest was a political defeat for the United States and for orthodoxy. This position became de rigueur within the international community and was adopted by the Population Council (Population Council, 1978: 113-126) and by many American demographers. Some argued, though, that integrating family planning into general development programs constituted no great challenge to orthodoxy since "it challenges none of the assumptions on which the need for population control is based" (Carder, 1974: 9). Distributing contraceptives as part of programs aimed at meeting basic needs might simply be a way of inducing greater numbers of the poor to accept and use them.

In one way, however, a developmentalist position was a change from orthodoxy. Assuming that development and fertility control could proceed hand in hand assumed a population problem significantly less virulent than the one perceived in the 1950s. Such a growth in optimism portended a difficult future for orthodoxy. In fact, it foreshadowed the arrival of revisionism.

\section{The rise of revisionism}

During the decade after Bucharest, orthodoxy lost much of the momentum that had swept it into dominance. Fears of famine lessened with the spread of the Green Revolution, and economic and demographic trends induced increasing numbers to question the most basic assumption of orthodoxy: that rapid population growth was a significant problem. Funding changes within the discipline and changes in the general political environment worked to improve the reception given these critics. By the end of the decade a stream of this critical thought had been labeled "revisionism."

Demeny (1986: 474) sees two dimensions to revisionism. On the surface it is simply optimism about whether (extreme revisionism) or to what extent (moderate revisionism) rapid population growth hinders develop- 
ment. Beneath the surface he detects a belief that the "invisible hand" (market forces) works to shape population processes in ways that correspond to the needs of society. This second dimension might be overstated, but those revisionists offering theoretical rationales for their optimism do often highlight the beneficial nature of many market-induced feedbacks to population change (National Research Council, 1986: 88-89).

\section{Internal factors}

But changes in empirical conditions more than in theoretical predispositions lay behind revisionism's rise. Orthodoxy had difficulty digesting the optimistic economic and demographic trends of the 1970s. Samuel Preston (1987: 628634), for example, explained the fall-off in "alarmist" discussion by pointing to the developing world's rapid rates of per capita economic growth (especially high in countries with market economies) and its declining fertility. The National Research Council's Population Growth and Economic Development: Policy Questions (1986), a document reflecting both dimensions of revisionism, noted on its first page the developing world's falling total fertility rate (from 6.2 in $1950-55$ to 4.1 in $1980-85$ ) and on page 5 the positive annual growth rates of real gross domestic product per capita (ranging from 2.4 percent to 3.5 percent for the entire developing world over the period 1950-60 to 196570 and approximating 5.5 percent in the East Asia and Pacific region over the period 1965-81). On this empirical basis the pessimism endemic to works relating population and development from the time of Coale and Hoover's 1958 study was laid open to doubt (1986: 4): "But it is clear that despite rapid population growth, developing countries have achieved unprecedented levels of income per capita, literacy, and life expectancy over the past 25 years."

There had always been certain empirical facts that questioned orthodox assumptions. The near-zero correlation between population growth and per capita economic growth within the developing world that led Preston (1987: 628 ) to conclude "population growth could not be an overriding factor in economic growth" had been noted 20 years earlier by Kuznets (1967: 190191) and Richard Easterlin (1967). The continued lack of statistical association between these two variables during the 1970s and 1980s gradually changed examination of this relationship into a revisionist enterprise: attention became focused on explaining the lack of association. In a similar fashion the construction of models of demographic-economic relations assumed a revisionist tinge. Early models showing a strong negative impact of population growth on development (Enke, 1963) were known to produce dramatically different results with but slight changes in initial assumptions (Leibenstein, 1969). After a decade of spreading fertility decline and continued economic growth, newer models incorporated changes in initial assumptions that less- 
ened the impact of population (Ahlburg, 1987: 514). Some, most notably Julian Simon (1977, 1981), were so emboldened by these trends as to present true heresy: population growth stimulates economic growth. Increasingly they were given a serious hearing.

A growing number of empirical studies also raised doubts about many orthodox assumptions. Orthodoxy assumed that high dependency ratios would increase expenditures for education and health and thereby reduce the funds available for more immediately productive investments. T. Paul Schultz (1987) found no clear relationship between percent of gross national product invested in education and age structure or rates of population growth. Orthodoxy assumed that high fertility would produce low rates of savings; Allen Kelley (1973) and Andrew Mason (1987, 1988) found the actual relationship more complicated than that. Children were not just a short-term source of expenditure for parents; they often could be a long-term form of "risk protection" (Cain, 1983) or even a kind of "savings" (Hammer, 1984). When the catastrophes predicted for a quarter of a century by orthodoxy never arrived, its assumptions were subjected to an increasingly sophisticated scrutiny.

With the aura of crisis surrounding population growth dissipating, the consensus it had bred ended. Agreement about the severity of the population problem had smoothed over tensions arising from the contradictory demands of objectivity and advocacy. The mid-century need for evidence documenting a demand for birth control might have led to the construction of less-thanobjective KAP surveys, ones that inflated the number of potential users of contraception (Hauser, 1967: 404; Marino, 1971). The need during the 1960s for successful family planning projects might have led researchers at the Population Council to tout demonstration projects as successes and not accurately portray their strengths and weaknesses (Warwick 1982: 62):

A staff member reported constant tension between those who wanted to show the usefulness of family planning and those who favored objective analysis of results no matter what their direction. Another individual was even more critical: "The evaluation is hogwash-it is like the KAP surveys. There is a conflict of interest between research and mission. There are strong pressures to slant the results toward selling the program."

As long as all agreed about the severity of the population problem, such conflicts tended to be resolved in favor of advocacy.

When that consensus broke in the 1970s, the tensions between advocacy and objectivity became less easily contained. Authors of orthodox works could no longer presume that readers would share their assumptions. The reception given the World Bank's World Development Report 1984, a sophisticated and moderate orthodox work with a developmentalist bent, illustrates the point. In a review symposium in this journal (Vol. 11, no. 1, 
1985) Easterlin, in the first of three major reviews, calls the report a "brief for the World Bank's official position" (p. 115) that places an incorrectly high priority on the need for family planning programs in poor countries and inappropriately legitimizes coercive "beyond family planning" measures (p. 119). Colin Clark (p. 120) finds the whole report "Malthusianism in retreat." Ronald Lee questions the Report's scholarship (pp. 128-129), calling it a "position paper for a point of view" that "brushed aside without serious consideration" a number of "revisionist views." Positive assessments are found only in the section devoted to brief "Comments."

\section{External factors}

The end of orthodoxy's hegemony within American demography, however, was not due simply to the presence of demographic and economic trends. These trends could be given an orthodox interpretation (Menken, 1986). The developing world's annual population growth rate for 1980-85 was 2.00 percent, virtually identical with what it had been in 1950-55 (2.10 percent). For sub-Saharan Africa that rate had increased over a full percentage point with no evidence of a fall in fertility (National Research Council, 1986: 3). Much needed to be done. The actual declines in fertility occurring during the 1970 s could be viewed as finally documenting the plausibility of orthodoxy's solution (Lapham and Mauldin, 1985); China's experience proved that government-sponsored fertility control efforts could work even in predominately agrarian societies. The negative association of total fertility rates and rates of increase in per capita income emerging within the developing world could be viewed as documenting the economic benefits of lower fertility (Coale, 1986: 98-99). There was even a growing consensus among Third World governments that rapid population growth significantly hindered development (Nortman, 1985: 8), indicating final acceptance of orthodoxy's message by its primary audience. With strong institutional support, orthodoxy could have held sway within American demography. The optimistic trends of the 1970s need not have proved more antithetical to its hegemony than the pessimistic ones of the 1950s and 1960s.

Institutional support, however, did not remain strong. The International Conference on Population at Mexico City in 1984 might have been what orthodoxy had hoped for Bucharest: a politically neutral occasion at which fertility control was universally acclaimed. But the US delegation ended that hope with a revisionist pronouncement: "First and most important, population growth is, of itself, a neutral phenomenon. It is not necessarily good or ill" (United States, 1984: 576). The changed position of the US delegation between 1974 and 1984 was not a simple reflection of changes in Third World economic and demographic conditions. Other factors clearly played a role. Similarly, external factors played a role in the end of orthodoxy's hegemony within American demography. 
A changed funding environment The theoretical course taken by American demography is largely determined by the work of academic demographers, those who train the discipline's future practitioners. Demography had successfully made a beachhead in American graduate education by 1970 due to high levels of foundation and government funding. The survival of the discipline, though, required the continual influx of outside funds since initially few universities were willing to subsidize it internally. Well into the 1970s demography was forced to be a reactive discipline responding quickly to changes in government and foundation funding decisions. Such changes happened with an uncomfortable frequency.

For a variety of reasons foundation support of demography shrank dramatically during the 1970s. Ideological shifts, such as John D. Rockefeller 3rd's developmentalist conversion, occurred. But even before Bucharest, the Ford and Rockefeller Foundations had already significantly cut back their funding of population activities. Apparently the stock market collapse of the early 1970s, which "dramatically affected" their finances, played a role (Caldwell and Caldwell, 1986: 134). By 1980 their population activities had been greatly scaled down. The Population Council, itself greatly affected by these moves, was forced to consider phasing out its graduate fellowship program and did finally have to significantly reduce its size (Kritz, 1988: 9, Table 1).

No doubt foundations assumed there would be less need for their funds with US government spending on population reaching major proportions by the early 1970s. With respect to advanced training and research, though, this assumption proved somewhat mistaken since both "USAID and the Ford Foundation, the major supporters of the U.S. population centers, phased out such support by the end of the 1970s" (Kritz, 1988: 9). Additionally, during the 1970s university-based centers increasingly found themselves competing with for-profit corporations for the available USAID contract research. Relying on USAID funding became a risky way of supporting population center activities. Grants from the Center for Population Research of the National Institute of Child Health and Human Development continued to provide core support for university population programs and fellowships for American students. Competition for them was great, however, and renewal became largely dependent upon high research output (Caldwell and Caldwell, 1986: 145). The $\$ 16$ million granted by the Hewlett and Mellon Foundations for international population work from 1978 to 1987 (Kritz, 1988: 12) has sustained some interest in this topic at American population centers but, overall, such interest has declined (Demeny, 1988: 477) along with its funding.

Academic demography reacted to funding vagaries by becoming leaner, more embedded within the university framework, and less policy oriented: "During the 1970s most programs decided that their future lay in becoming orthodox disciplinary components of the universities. Even among the greatest enthusiasts for changing the world there was a growing concern with 
objectivity and with playing a greater role within the university than outside it" (Caldwell and Caldwell, 1986: 144). With advancement dependent upon scholarly output, demographers came to emphasize social scientific quality, not policy relevance, in their research. This altered structural setting diffused American demography's former focus on orthodox concerns and lessened institutional constraints inhibiting a critical examination of orthodox assumptions. An outside constituency was developing eager for such critiques.

A changed political environment Federal government support for orthodoxy, measured by amounts appropriated for fertility control work, did not shrink like that of foundations during the 1970s, but doubts arose about the future. Supporting fertility control efforts began to entail costs for politicians. President Richard Nixon lost few votes in 1970 by signing the Family Planning and Population Research Act. By 1973, though, an amendment was passed that barred the use of funds when abortion was involved. As the abortion controversy grew in political significance, sensitivity to a range of reproductive issues was heightened.

The Supreme Court's 1973 decision legalizing abortion spawned the Right to Life movement. Within two years a national organization had been created of significant political strength. Although a constitutional amendment outlawing abortion proved beyond its power, the movement was able to have laws passed forbidding the use of public funds for abortions and to induce a significant proportion of politicians to publicly oppose abortion and the provision of contraceptives to minors without parental approval. A set of reproductive issues proved capable of mobilizing social conservatives, often religiously motivated, across denominational and regional boundaries. A reproductive plank was added to the platform of the New Right.

During the early 1960s orthodoxy would have been little troubled by the reproductive litmus test of the New Right since voluntary family planning (not including abortion) was its prescription for fertility control. But when doubts had surfaced over whether population control would succeed democratically (Davis, 1967), some had argued that propaganda, incentives, maybe even disincentives might be needed. Garrett Hardin (1968), with his evocative image of the Commons, provided the rationale for moving beyond family planning: pursuit of individual interest can, at times, work against the collective interest. Those believing that high fertility significantly worsened the commonweal thought governments might have the right (perhaps the duty) to limit individual reproductive freedom.

When a number of Asian countries actually moved in this direction during the 1970s, orthodoxy faced a dilemma. These programs, especially China's and Singapore's, proved that remarkably quick fertility reductions were possible. Yet stories of Indian teenagers being forcibly given vasectomies and images of Chinese women, seven months pregnant, being coerced into 
accepting abortions provoked outrage in most Americans, including many demographers. Heralding these programs as great successes or as blueprints for others to follow promised to be politically dangerous. Once millions had their fertility restricted, the academic debate over the seriousness of the population problem assumed deepened political and ethical dimensions. Among the orthodox a remarkable silence came to surround the issue.

Social conservatives wishing to garner support for their domestic agenda, however, were not silent about these stories. They were potent weapons. Connections to the domestic political agenda could be made. Were not US taxpayers' monies supporting these programs, and even if not directly paying for abortions did they not "free up" the monies that did? When publicly funded family planning clinics in the United States gave contraceptives to minors without notifying their parents, was not our government similarly intervening in decisions that ought to be made by families? Were not publicly funded abortions for the American poor a form of population control?

Ronald Reagan was elected President in 1980 by a coalition of social and economic conservatives whose agendas only occasionally overlapped (Jackson and Vinovskis, 1983: 79). At first the orthodoxy common to past administrations, both conservative Republican and liberal Democratic, was adopted (Finkle and Crane, 1985: 16-17). An International Conference on Population scheduled for an election year posed problems, however. Simply acknowledging the existence of a population problem would be interpreted by social conservatives as an apology for abortion and state-mandated contraception. The Reagan administration's embrace of revisionism was no accident. Contending that population growth produced no great detrimental effect on development efforts undercut the rationale for all "beyond family planning" programs. A firm position opposing them and abortion could thereby be adopted. Contending that economic stagnation was more the result of excessive state control of the economy than of population growth could simultaneously garner the support of economic conservatives. The success of market-oriented Pacific-rim economies and the poor performance of state-controlled ones had clearly reduced the salience of orthodoxy's Cold War arguments.

Revisionism gained exposure from the administration's embrace. With orthodoxy still holding sway in Congress, sounds from the academic debate reverberated in the policy arena. Because of support by the United Nations Fund for Population Activities of family planning activities in China, the United States stopped contributing to the Fund. When articles on abortion continued to appear in International Family Planning Perspectives, its government subsidy was ended. Such were the actions of an administration that used revisionism to relieve concern about a population crisis so as to more easily advance a domestic political agenda. They drew more criticism than 
praise from academic demographers and confirmed in the minds of many the desirability of moving the discipline away from dependence on government funds.

\section{Conclusions}

A combination of factors, internal and external, lay behind the emergence of orthodoxy and the rise of revisionism. Changes in demographic conditions requiring the modification of old theories, and changes in concerns altering what demographers looked at and how they went about "seeing," both occurred. Currently the relationship between population and development, the central topic of demography since the time of Malthus, is being approached from many directions. While revisionists question the existence of a demographic stumbling block to development and the orthodox applaud their success at reducing its size, others are reviving transition theory and are isolating development "thresholds" associated with fertility decline (Kirk, 1971; Coale, 1973, 1984; Cecheli and Kirk, 1975; Beaver, 1975; Caldwell, 1976; Cutright and Hargens, 1984). Still others, spurred on by uniformly low and often below-replacement fertility levels, are redirecting attention to the population/development interactions of the developed world (Espenshade, 1978; Campbell, 1979; Davis, Bernstam, and Ricardo-Campbell, 1986).

Does the current multiplicity of concerns, questions, and assumptions indicate that demography in the United States is undergoing a fundamental shift in direction? What will be the discipline's perspective on population and development at the close of the present century? These are questions not easily answered. Few of the formulators of transition theory in 1945 would have predicted the rise of orthodoxy a decade later. Few at Bucharest in 1974 would have predicted the US delegation's position at Mexico City in 1984. Few now can predict what questions demographers will seek to answer at the end of the century, what significance they will draw from analysis of trends, or what policy import their findings will have. Perhaps a global recession will stall fertility decline and begin a period of clear negative association between rates of increase in population and per capita income. Perhaps fear of depopulation will evoke calls to demographers for reproductive survival plans. With the discipline's course influenced by an interplay of internal and external factors, the one certainty is that periodic shifts in perspective will continue.

\section{Note}

An earlier version of this article was written for and presented at the Annual Meeting of the Population Association of America, New
Orleans, 21-23 April 1988, as part of the session "Two centuries after Malthus: The history of demography." 


\section{References}

Ahlburg, Dennis A. 1987. "The impact of population growth on economic growth in developing nations: The evidence from macroeconomic-demographic models," in Johnson and Lee, 1987, pp. 479-522.

Bachrach, Peter, and Elihu Bergman. 1973. Power and Choice: The Formation of American Population Policy. Lexington, Mass.: Lexington Books.

Barclay, William, Joseph Enright, and Reid Reynolds. 1970. "The social context of U.S. population control programs in the Third World," paper presented at the Annual Meeting of the Population Association of America, Atlanta.

Beaver, Steven E. 1975. Demographic Transition Theory Reinterpreted: An Application to Recent Natality Trends in Latin America. Lexington, Mass.: Lexington Books.

Beebe, Gilbert. 1942. Contraception and Fertility in the Southern Appalachians. Baltimore: Williams and Wilkins.

Berelson, Bernard. 1964. "National family planning programs: A guide," Studies in Family Planning No. 5. Supplement.

- 1969. "Beyond family planning," Studies in Family Planning No. 38: 1-16.

- 1971. "Population policy: Personal notes," Population Studies 25, no. 2: 173-182.

Bogue, Donald. 1965. "Family planning research: An outline of the field," in Family Planning and Population Programs, ed. Bernard Berelson et al. Chicago: University of Chicago Press, pp. 721-736.

Cain, Mead. 1983. "Fertility as an adjustment to risk," Population and Development Review 9, no. 4: 688-702.

Caldwell, John C. 1976. "Toward a restatement of demographic transition theory," Population and Development Review 2, nos. 3/4: 321-366.

- and Pat Caldwell. 1986. Limiting Population Growth and the Ford Foundation Contribution. Dover, N. H.: Frances Pinter.

Campbell, Arthur A. (ed.). 1979. Social, Economic and Health Aspects of Low Fertility. NIH Publication No. 80-100. Washington, D.C.: National Institutes of Health.

Carder, Michael. 1974. "A family quarrel?: 'Developmentalism' or family planning," Concerned Demography 4, no. 2: 3-12.

Cecheli, Frank and Dudley Kirk. 1975. "Modemization and the demographic transition in Latin America and the Caribbean," Economic Development and Cultural Change 23, no. 3: $391-420$.

Coale, Ansley J. 1956. "The effects of changes in mortality and fertility on age composition," Milbank Memorial Fund Quarterly 34, no. 1: 79-114.

- 1973. "Transition theory," in International Union for the Scientific Study of Population, International Population Conference, Vol. 1. Liège: IUSSP, pp. 53-71.

- 1984. "The demographic transition," The Pakistan Development Review 23, no. 4: 531552.

- 1986. "Population trends and economic development," in Menken, 1986, pp. 96104.

- and Edgar M. Hoover. 1958. Population Growth and Economic Development in Low-Income Countries. Princeton, N.J.: Princeton University Press.

Cutright, Phillips, and Lowell Hargens. 1984. "The threshold hypothesis: Evidence from less developed Latin American countries, 1950 to 1980," Demography 21, no. 4: 459-473.

Davis, Kingsley. 1945. "The world demographic transition," Annals of the American Academy of Political and Social Science 237: 1-11.

1948. Human Society. New York: Macmillan.

- 1950. "Population and the further spread of industrial society," Proceedings of the American Philosophical Society 95, no. 1: 8-19.

- 1951. The Population of India and Pakistan. Princeton, N.J.: Princeton University Press. . 1953. "Future population trends and their significance," in Transactions of the Eighteenth 
North American Wildlife Conference. Washington, D.C.: Wildlife Management Institute, pp. $8-21$.

. 1954. "Fertility control and the demographic transition in India," in The Interrelations of Demographic, Economic, and Social Problems in Selected Underdeveloped Areas. New York: Milbank Memorial Fund, pp. 66-89.

1956a. "The amazing decline of mortality in underdeveloped areas," American Economic Review 46, no. 2: 305-318.

- 1956b. "Population and power in the free world," in Population Theory and Policy, ed. Joseph Spengler and Otis Dudley Duncan. Glencoe, Ill.: The Free Press, pp. 342-356.

. 1956c. "The unpredicted pattern of population change," Annals of the American Academy of Political and Social Science 305: 53-59.

. 1958a. "Recent population trends in the new world: An over-all view," Annals of the American Academy of Political and Social Science 316: 1-10.

- 1958b. "The political impact of new population trends," Foreign Affairs 36, no. 2: 293-301.

- 1967. "Population policy: Will current programs succeed?" Science 158 (10 November): $730-739$.

- Mikhail S. Bernstam, and Rita Ricado-Campbell (eds.). 1986. Below-Replacement Fertility in Industrial Societies: Causes, Consequences, Policies, Supplement to Population and Development Review 12.

Demeny, Paul. 1986. "Population and the invisible hand," Demography 23, no. 4: 473-488.

- 1988. "Social science and population policy," Population and Development Review 14, no. 3: 451-479.

Demerath, Nicholas J. 1976. Birth Control and Foreign Policy. New York: Harper and Row.

Easterlin, Richard A. 1967. "Effects of population growth on the economic development of developing countries," Annals of the American Academy of Political and Social Science 369: 98-108.

Enke, Stephen. 1963. Economics for Development. Englewood Cliffs, N.J.: Prentice-Hall.

Espenshade, Thomas J. 1978. "Zero population growth and the economies of developed nations," Population and Development Review 4, no. 4: 645-680.

Finkle, Jason L., and Barbara B. Crane. 1975. "The politics of Bucharest: Population, development, and the new international economic order," Population and Development Review 1, no. 1: 87-114.

- and Barbara B. Crane. 1985. "Ideology and politics at Mexico City: The United States at the 1984 International Conference on Population," Population and Development Review 11, no. 1: 1-28.

Ford Foundation. 1985. "The Ford Foundation's work in population," Ford Foundation Working Paper. New York.

Gordon, Linda. 1974. "The politics of population: Birth control and the eugenics movement," Radical America 8, no. 4: 66-97.

. 1976. Woman's Body, Woman's Right. New York: Grossman.

Hagen, Everett E. 1958. "World economic trends and living standards," in Hauser, 1958, pp. 118-136.

Hammer, Jeffrey S. 1984. "Population growth and savings in less developed countries," background paper prepared for the World Development Report 1984. Washington, D.C.: World Bank.

Hardin, Garrett J. 1968. "The tragedy of the commons," Science 162 (13 December): 12431248.

Hauser, Philip M. 1954. "Research needs and suggested projects," in The Interrelations of Demographic, Economic, and Social Problems in Selected Underdeveloped Areas. New York: Milbank Memorial Fund, pp. 187-191.

(ed.). 1958. Population and World Politics. Glencoe, Ill.: The Free Press. 
1964. "Demographic dimensions of world politics," in The Population Crisis and the Use of World Resources, ed. Stuart Mudd. Bloomington: Indiana University Press, pp. 109123.

1967. "Family planning and population programs: A book review article," Demography 4, no. 1: 397-414.

Hodgson, Dennis. 1983. "Demography as social science and policy science," Population and Development Review 9, no. 1: 1-34.

Jackson, John E. and Maris A. Vinovskis. 1983. "Public opinion, elections, and the 'single issue," " in The Abortion Dispute and the American System, ed. Gilbert Steiner. Washington, D.C.: The Brookings Institution, pp. 64-81.

Johnson, D. Gale, and Ronald D. Lee. 1987. Population Growth and Economic Development: Issues and Evidence. Madison: University of Wisconsin Press.

Johnson, Lyndon B. 1966. "President Johnson's Message to Congress on foreign assistance," The State Department Bulletin 54, no. 1392.

Kelley, Allen C. 1973. "Population growth, the dependency rate, and the pace of economic development," Population Studies 27, no. 3: 405-414.

Kirk, Dudley. 1944. "Population changes and the postwar world," American Sociological Review 9, no. 1: 28-35.

- 1971. "A new demographic transition?," in National Academy of Science, Rapid Population Growth: Consequences and Policy Implications, Vol 2. Baltimore: Johns Hopkins University Press, pp. 123-147.

Kocher, James E. 1973. Rural Development, Income Distribution and Fertility Decline. New York: The Population Council.

Kritz, Mary M. 1988. "Building demographic capacity for population policy in developing countries," paper presented at the Annual Meeting of the Population Association of America, New Orleans, 21-23 April.

Kuznets, Simon. 1958. "Regional economic trends and levels of living," in Hauser (1958), pp. 79-117.

- 1967. "Population and economic growth," Proceedings of the American Philosophical Society 111, no. 3: 170-193.

Lapham, Robert J., and W. Parker Mauldin. 1985. “Contraceptive prevalence: The influence of organized programs," Studies in Family Planning 16, no. 3: 117-137.

Leibenstein, Harvey. 1954. A Theory of Economic-Demographic Development. Princeton, N.J.: Princeton University Press.

_ 1969. "Pitfalls in benefit-cost analysis of birth prevention," Population Studies 23, no. 2: $161-170$.

Lorimer, Frank. 1951. "Dynamics of age-structure in a population with initially high fertility and mortality," Population Bulletin of the United Nations No. 1 (December): 31-41.

Mamdani, Mahmood. 1972. The Myth of Population Control. New York: Monthly Review Press.

Marino, Anthony. 1971. "KAP surveys and the politics of family planning," Concerned Demography 3, no. 1: 36-75.

Mason, Andrew. 1987. "National saving rates and population growth: A new model and new evidence," in Johnson and Lee, 1987, pp. 523-560.

- 1988. "Saving, economic growth, and demographic change," Population and Development Review 14, no. 1: 113-144.

Mass, Bonnie. 1972. The Political Economy of Population Control in Latin America. Montreal: Editions Latin America.

- 1974. "An historical sketch of the American population control movement," International Journal of Health Services 4, no. 4: 651-676.

Mauldin, W. Parker, Nazli Choucri, Frank W. Notestein, and Michael Teitelbaum. 1974. "A report from Bucharest," Studies in Family Planning 5, no. 12: 357-395.

Menken, Jane (ed.). 1986. World Population and U.S. Policy: The Choices Ahead. New York: W. W. Norton. 
Moore, Wilbert. 1945. Economic Demography of Eastern and Southern Europe. Geneva: League of Nations.

National Research Council. 1986. Population Growth and Economic Development: Policy Questions. Washington, D.C.: National Academy Press.

Nelson, R. R. 1956. "A theory of the low-level equilibrium trap in underdeveloped countries," American Economic Review 46, no. 5: 894-908.

Nortman, Dorothy L. 1985. Population and Family Pianning Programs: A Compendium of Data through 1983, 12th edition. New York: The Population Council.

Notestein, Frank W. 1943. "Some implications of population change for post-war Europe," Proceedings of the American Philosophical Society 87, no. 2: 165-174.

- 1945. "Population-The long view," in Food for the World, ed. Theodore W. Schultz. Chicago: University of Chicago Press, pp. 36-57.

- 1950. "The population of the world in the year 2000," Journal of the American Statistical Association 45 (September): 335-345.

- 1953. "Economic problems of population change," in Proceedings of the Eighth International Conference of Agricultural Economists. New York: Oxford University Press, pp. 1331.

- 1954. "Discussion," in The Interrelations of Demographic, Economic, and Social Problems in Selected Underdeveloped Areas. New York: Milbank Memorial Fund, 166-169.

- 1968. "The Population Council and the demographic crisis of the less developed world," Demography 5, no. 2: 553-561.

- 1971. "Reminiscences: The role of foundations, the Population Association of America, Princeton University and the United Nations in fostering American interest in population problems," Milbank Memorial Fund Quarterly 49, no. 4, part 2: 67-84.

- 1982. "Demography in the United States: A partial account of the development of the field," Population and Development Review 8, no. 4: 651-687.

Piotrow, Phyllis Tilson. 1973. World Population Crisis: The United States Response. New York: Praeger.

Population Council. 1977. "On the origins of the Population Council," Population and Development Review 3, no. 4: 493-502.

. 1978. The Population Council: A Chronicle of the First Twenty-Five Years, 1952-1977. New York: The Population Council.

Pradervand, Pierre. 1970. "International aspects of population control," Concerned Demography 2, no. 2 (December): 1-16.

Preston, Samuel H. 1987. "The social sciences and the population problem," Sociological Forum 2, no. 4: 619-644.

Rich, William. 1973. Smaller Families Through Social and Economic Progress. Washington, D.C.: Overseas Development Council.

Rockefeller, John D. 3rd. 1974. "Population growth: The role of the developed world," Lecture Series on Population. Liège: International Union for the Scientific Study of Population. Reprinted in full in Population and Development Review 4, no. 3: 509-516.

Ryabushkin, T. V. 1954. "Social aspects of population structure and movement," World Population Conference, 1954, Vol. 5: 1032-1038. New York: United Nations.

Schultz, T. Paul. 1987. "School expenditures and enrollments, 1960-80: The effects of income, prices, and population growth," in Johnson and Lee, 1987, pp. 413-476.

Shils, Edward. 1970. "Tradition, ecology, and institution in the history of sociology," Daedalus 99, no. 4: 760-825.

Simon, Julian. 1977. The Economics of Population Growth. Princeton, N.J.: Princeton University . Press.

. 1981. The Ultimate Resource. Princeton, N.J.: Princeton University Press.

Stix, Regine, and Frank W. Notestein. 1940. Controlled Fertility. Baltimore: Williams and Wilkins. 
Stolnitz, George. 1955. "A century of intemational mortality trends: I," Population Studies 9. no. 1: 25-55.

1956a. "A century of international mortality trends: II," Population Studies 10, no. 1: $17-42$.

1956b. "Comparisons between some recent mortality trends in underdeveloped areas and historical trends in the West," in Trends and Differentials in Mortality. New York: Milbank Memorial Fund, pp. 26-34.

. 1958. "The revolution in death control in nonindustrial countries," Annals of the American Academy of Political and Social Science 316: 94-101.

Stycos, J. Mayone. 1967. "Preliminary report to H.E.W. on the status of demographic training in the United States," Population Index 33, no. 3: 360-361.

. 1974. "Demographic chic at the U.N.," Family Planning Perspectives 6, no. 3: 160-164.

Taeuber, Irene. 1952. "The future of transitional areas," in World Population and Future Resources, ed. Paul Hatt. New York: American Book Co., pp. 25-38.

. 1958. "Population and political instabilities in underdeveloped areas," in Hauser, 1958, pp. 237-259.

. 1965. "Demographic instability: Resolution or retrogression in Asia," in Population Growth: Threat to Peace?, ed. William E. Moran, Jr. New York: P. J. Kenedy \& Sons, pp. 60-79.

Thompson, Warren. 1930. Population Problems. New York: McGraw-Hill.

. 1946. Population and Peace in the Pacific. Chicago: University of Chicago Press.

United States. 1984. "US policy statement for the International Conference on Population," Population and Development Review 10, no. 3: 574-579.

Unseem, Michael. 1976. "Government influence in the social science paradigm," Sociological Quarterly 17, no. 2: 146-161.

Vance, Rupert. 1952. "The demographic gap: Dilemma of modemization programs," in Approaches to Problems of High Fertility in Agrarian Societies. New York: Milbank Memorial Fund, pp. 9-18.

Warwick, Donald P. 1982. Bitter Pills: Population Policies and Their Implementation in Eight Developing Countries. London: Cambridge University Press.

Watnick, Morris. 1952. "The appeal of communism to the underdeveloped peoples," Economic Development and Cultural Change 1, no. 1: 22-36.

World Bank. 1974. Population Policies and Economic Development. A World Bank Staff Report. Baltimore: Johns Hopkins University Press. 1984. World Development Report 1984. New York: Oxford University Press. 